Ann. Zootech., 1980, 29, $\mathrm{n}^{\circ}$ h. s., 53-64.

\title{
Survey of the protein feeding standards used in the COST countries
}

\author{
Y. GEAY \\ Laboratoire de la Production de Viande \\ Centre de Recherches de Clermont-Ferrand INRA, \\ Theix, 63110 Beaumont (France)
}

\begin{abstract}
Résumé
Étude des apports protéiques recommandés dans les différents pays de la communauté économique européenne et dans les pays associés
\end{abstract}

A l'occasion de ce séminaire, le groupe de scientifiques chargés de la coordination des études de nutrition dans la C.E.E. a demandé à chacun des pays de la Communauté, ainsi qu'aux pays associés, une description de leurs systèmes d'apports azotés recommandés pour les bovins en croissance et à l'engrais. La Belgique, le Danemark, la République Fédérale Allemande, la Finlande, la France, la Grèce, l'Irlande, les Pays-Bas, la Suède, la Suisse, le Royaume Uni et la Yougoslavie ont répondu. Leurs textes sont présentés en annexe de ce recueil. L'étude présentée ci-après avait pour objectif de résumer les caractéristiques des différentes normes azotées et d'en tenter une analyse critique.

Unités : dans la plupart des pays, les apports azotés recommandés sont exprimés en MAD (en $g / j$ ou en $g$ par unité d'énergie nette ou par unité d'énergie métabolisable). L'expression en MAT n'apparaît que pour quelques types d'animaux sous forme de valeur moyenne pour la période d'engraissement (taurillons en Belgique) ou comme unité complémentaire aux MAD (Irlande).

Seule la France, et bientôt le Royaume Uni, proposent un nouveau mode d'expression reposant sur l'estimation de la quantité de protéines digestibles (réellement ou apparemment) dans l'intestin grêle.

Facteurs de variation des apports recommandés : les divers facteurs de variation de la quantité de protéines fixées par l'animal (sexe, génotype, poids vif, gain de poids) et qui conditionnent les apports recommandés ne sont pas tous pris en compte. Ainsi, le sexe et le gain de poids sont des critères de variation des apports azotés dans 6 à 7 pays sur 12 . La Suède pour les bœufs, taurillons et génisses, et la France pour les taurillons sont les seuls pays à tenir compte du génotype. Le poids en revanche fait l'unanimité.

Comparaison des apports recommandés en MAD : trois types d'analyses ont été réalisés pour comparer les apports en MAD recommandés par les divers pays. Le premier montre que les apports sont formulés de façon différente, selon les pays, en fonction du poids et du gain de poids. La seconde analyse quantifie ces apports pour un même poids et un même gain de poids et met en évidence des écarts importants entre pays (32 à 50 p. 100 de la valeur moyenne pour les taurillons Frisons, 17 à 66 p. 100 pour les génisses Frisonnes). La troisième analyse traduit ces écarts en $\mathrm{g}$ de tourteau de soja complémentaire de diverses rations. Elle montre ainsi que le système MAD conduit à des différences d'apports de tourteau entre pays, variables selon les régimes.

Les nouveaux systèmes d'apports recommandés : les nouveaux systèmes expriment la valeur azotée des aliments et les besoins des animaux en acides aminés réellement ou 
apparemment digestibles dans l'intestin. Ce mode d'expression permet d'être indépendant de la nature de la ration. L'étude présente ici les principaux avantages de ces systèmes et compare les deux plus évolués pour les bovins en croissance et à l'engrais (I.N.R.A., 1978 et A.R.C., 1980) sur la base des quantités de tourteaux complémentaires de 2 rations. Elle met en évidence des différences importantes d'apports de tourteau dues essentiellement au mode de calcul des besoins physiologiques des animaux ainsi qu'aux valeurs adoptées pour l'efficacité d'utilisation des acides aminés absorbés au niveau de l'intestin.

\section{Introduction}

In order to examine the current situation regarding the different standards proposed for protein in the EEC and associated countries, the Nutrition Management Scientific Group of the EEC asked each participating country to give a description of its feeding standards. Replies were received from : Belgium (B), Denmark (DK), the Federal Republic of Germany (D), Finland (SF), France (F), Greece (GR), Ireland (EIR), the Netherlands (NL), Sweden (S), Switzerland (CH), the United Kingdom (UK) and Yugoslavia (YU). Their papers will be summarised here and some comments will be made on different examples of diets.

\section{1. - Characteristics of protein feeding standards (table 1)}

$$
\text { A. 一 Units }
$$

For most countries, protein allowances are expressed as digestible crude protein in g/day. However, three countries using this type of unit (Denmark, Finland and Sweden) related the recommanded DCP to energy intake (Net Energy or Metabolisable Energy) and expressed them respectively in DCP (g)/d/SFU or FFU and DCP $(\mathrm{g}) / \mathrm{d} / \mathrm{MJ}$ of ME.

In Belgium, DCP (as a percentage of dry matter) or in Ireland, CP (in $\mathrm{g} / \mathrm{d}$ ) are mentioned, either for a particular type of production (young bulls in Belgium) or as an additional unit (in Ireland).

In France, since 1978, a new system has been proposed (INRA, 1978) to replace the DCP system. It is called the PDI system in which the requirements of animals are expressed in true protein truly digestible in the small intestine.

\section{B. - Factors of variation considered}

The protein gain varies with sex, breed, liveweight and liveweight gain (cf. RoBELIN and DAENICKE, 1980). The protein allowances also vary.

a. Sex

Except in Ireland and in the United Kingdom, sex is taken into account in all the protein feeding standards used for fattening animals. For growing animals, however, only Denmark, Germany, France, Sweden and Switzerland considered males and females separately. 


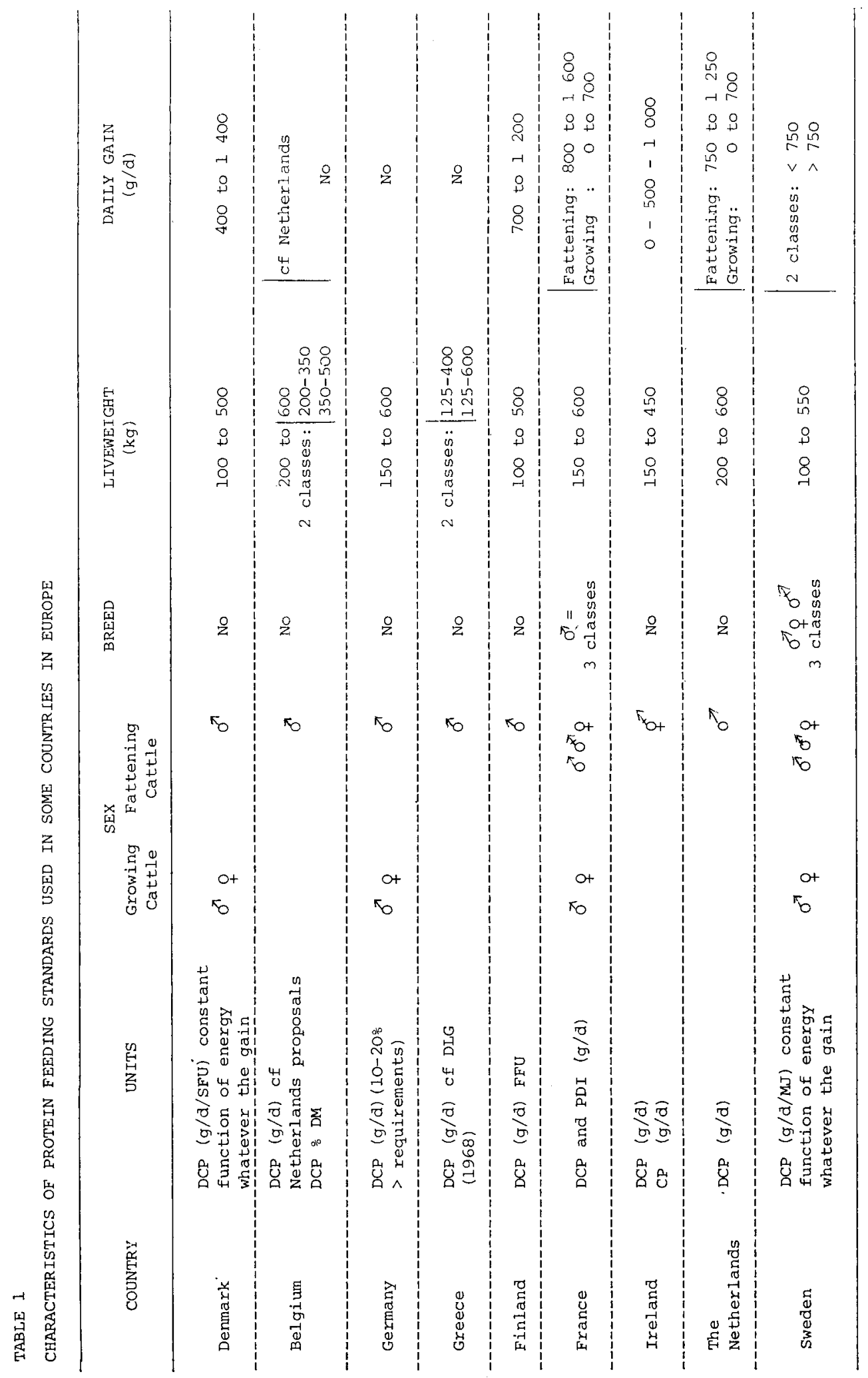




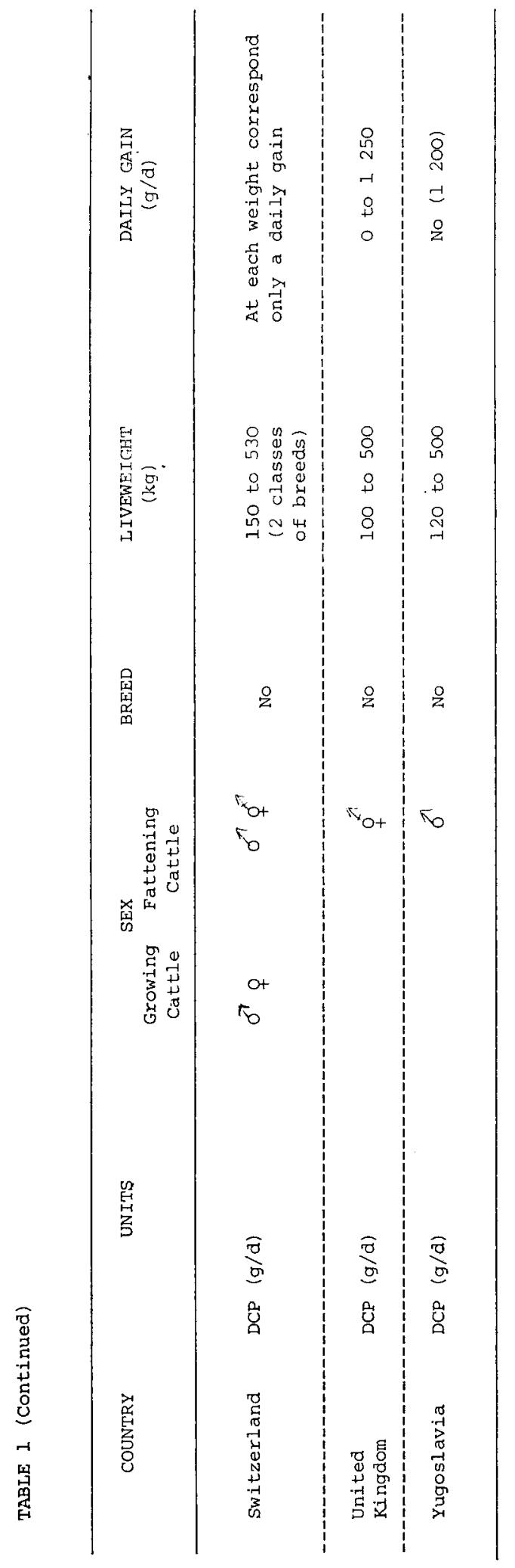




\section{b. Breed}

Over the last ten years many authors have observed differences between breeds in body composition at slaughter, but very few of them have measured the daily protein retention (GEAY et al., 1976 ; ROHR and DAENICKE, 1978 ; RoBelin et al., 1978). So protein standards do not usually take this factor into account. Only two countries are interested in it for fattening animals : Sweden for young bulls, steers and heifers, and France for bulls.

\section{c. Liveweight}

All countries in the survey modulate the protein allowances as a function of liveweight. The range of liveweight variation sometimes fits the different types of production (France, Greece, Switzerland). In France and Switzerland, this weight range depends on the breed.

\section{d. Daily gain}

Seven countries out of twelve (Denmark, Finland, France, Ireland, The Netherlands, Sweden and the United Kingdom) modulate the recommended protein with daily gain for all types of animals. Switzerland considered only a mean daily gain at each weight, depending on the type of production. Belgium, Germany and Greece recommended respectively a mean value for young bull production throughout the fattening period, at each weight or in a range of liveweights. Yugoslavia gave a mean value that amounts to $1.2 \mathrm{~kg} / \mathrm{d}$.

\section{2. - Comparison of protein allowances expressed as DCP units} made :

To compare the different protein standards, three types of analyses were

1. The purpose of the first analysis was to describe the evolution of protein allowances with liveweight and daily liveweight gain. Thus (figure 1) they increase more and more with the liveweight in three countries $(\mathrm{CH}, \mathrm{DK}, \mathrm{SF})$, vary linearly with the weight in Ireland and Sweden, and increase less and less in the other countries (D, GR, F, NL, UK, YU). This evolution can be explained if maintenance requirements are to be related to a power of liveweight lower than 1 , and if we consider that retained protein per $\mathrm{kg}$ of gain decreases as liveweight increases.

For a constant weight, and for $100 \mathrm{~g}$ of supplementary gain, the recommended DCP increases more and more with daily gain for some countries (SF, DK, S), but decreases for others (CH, F, NL, UK). This last evolution is more relevant as long as the protein gain content decreases when growth rate increases.

In Belgium, Germany, Greece and Yugoslavia, protein standards for young bulls are practically independent of gain. Indeed they correspond to optimum allowances that enable the animals to express their growth potential.

2. In the second analysis the two most widely used animals in the EEC and associated countries were taken into consideration : young fattening bulls and growing heifers, both of the Friesian breed. The recommended $D C P$ for the former animal at 200 and $500 \mathrm{~kg}$ and for the latter at 200 and $400 \mathrm{~kg}$, were compared. 


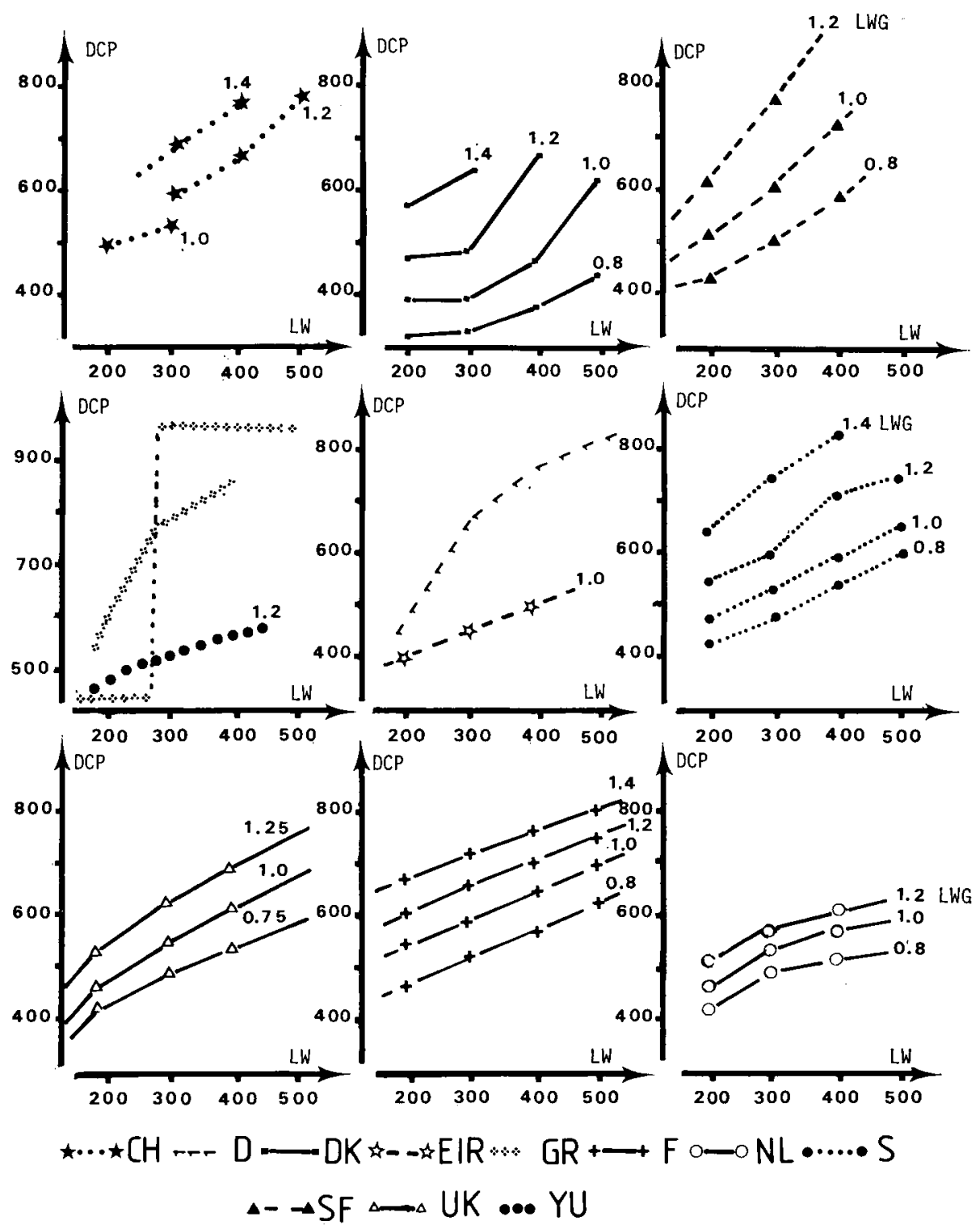

Fig. 1. - Evolution of protein allowances ( $D C P$ in $\mathrm{g} / \mathrm{d}$ ) with liveweight ( $L W$ in $\mathrm{kg}$ ) and daily liveweight gain ( $L W G$ in $\mathrm{kg} / \mathrm{d}$ ) in different countries.

Most recommended allowances for young Friesian bulls converged at $200 \mathrm{~kg}-800 \mathrm{~g} / \mathrm{d}$ and at $500 \mathrm{~kg}-700 \mathrm{~g} / \mathrm{d}$ (figure 2), although variation occurs when weight increases. In spite of this, only allowances recommended by DK and D, and GR at $500 \mathrm{~kg}$ differed greatly from the others : DK standards are lower for all gains less than or equal to $1000 \mathrm{~g} / \mathrm{d}$ at $200 \mathrm{~kg}$ and to $900 \mathrm{~g} / \mathrm{d}$ at $500 \mathrm{~kg}$ (figure 2); D standard at any weight and GR standard at $500 \mathrm{~kg}$ are 
1) FATTENING FRIESIAN BULLS
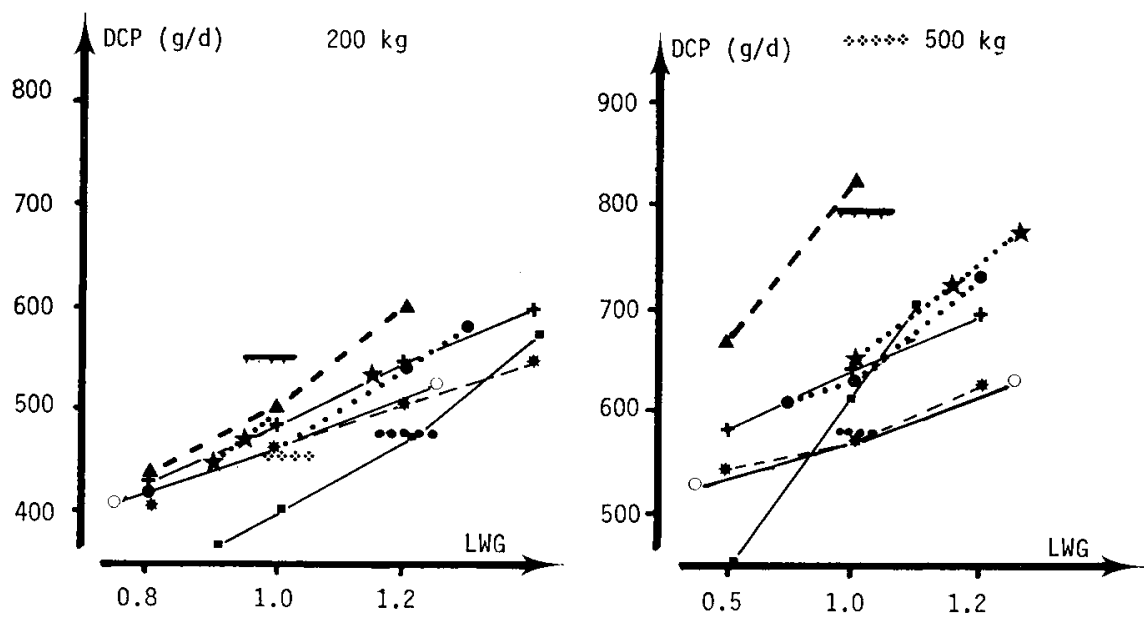

2) GROWING FRIESIAN HEIFERS
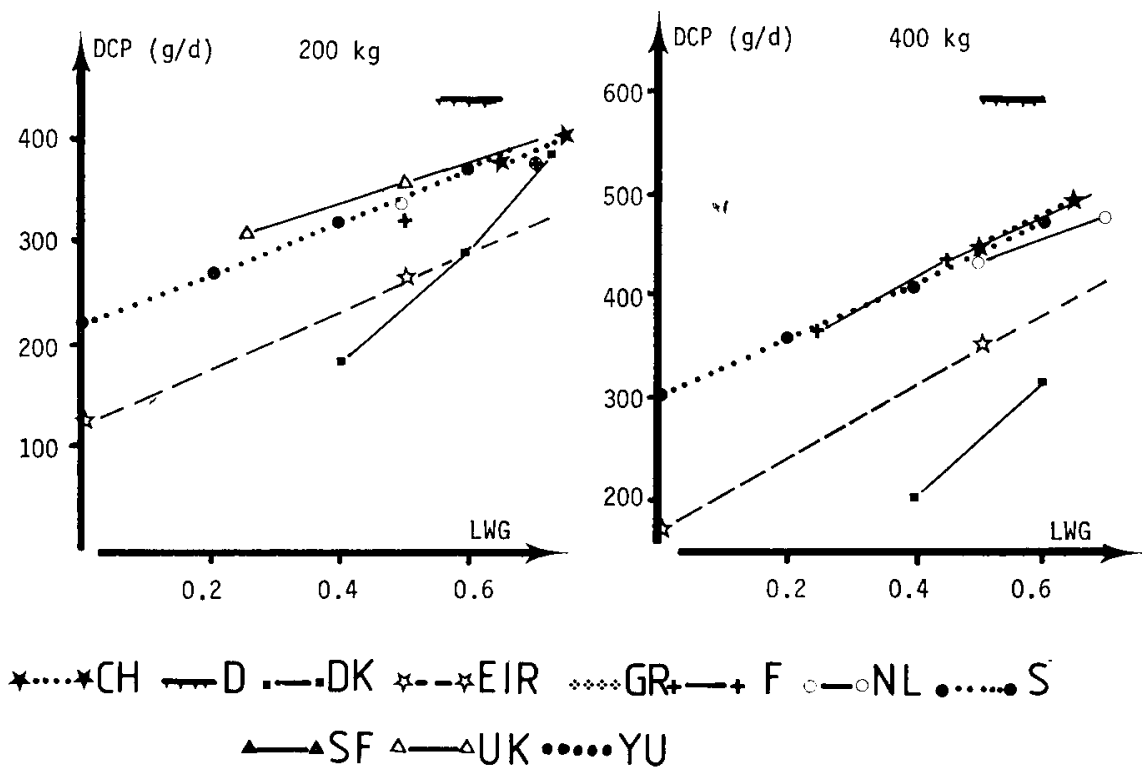

FIG. 2. - Evolution of protein allowances (DCP in $g / d$ ) with liveweight and daily liveweight gain for fattening Friesian bulls and growing Friesian heifers in different countries.

much higher whatever the gain. On the whole, protein standards for $1000 \mathrm{~g}$ of gain vary between 400 and $550 \mathrm{~g}$ of DCP at $200 \mathrm{~kg}$ which amounts to 32 per cent of the mean value, and from 570 to $950 \mathrm{~g}$ of DCP at $500 \mathrm{~kg}$ which amounts to about 50 per cent of the mean value. 
For growing Friesian heifers, the absolute and relative values of the differences between the two extreme standards are lower for $200 \mathrm{~kg}$ of liveweight ( 300 to $420 \mathrm{~g}$ of $\mathrm{DCP} / \mathrm{d}$, or 17 per cent of the mean value between 600 and $700 \mathrm{~g}$ of gain) (fig. 2). The differences are greater at $400 \mathrm{~kg}$ (between 300 and $600 \mathrm{~g}$ of DCP, or 66 per cent of the mean value) (fig. 2). The Danish and German standards are also the two extremes.

3. The purpose of the third analysis was to express the preceding divergences in $\mathrm{g}$ of cake or urea given with barley as a supplement to different forages. Three diets were taken into consideration : 1) for young Friesian bulls (200 kg $1000 \mathrm{~g} / \mathrm{d})$ : grass silage, maïze silage and dehydrated sugar beet pulp associated with straw ; 2$)$ for heifers $(200 \mathrm{~kg}-700 \mathrm{~g} / \mathrm{d})$ these silages plus meadow hay. In each case we assumed that the amount of forages consumed was the same for all countries, as were the total energy requirements (4 UFV for the young Friesian bulls and 3.5 UFL for the Friesian heifers). Only barley, cake (soyabean or peanut) or urea supplies vary according to the different protein standards.

For the fattening diets of young bulls, the complementary soyabean supply varied according to countries (fig. 3) from 0 to $320 \mathrm{~g}$ with grass silage, from 300 to $670 \mathrm{~g}$ with maize silage and from 440 to $780 \mathrm{~g}$ with dehydrated sugar beet pulp. Whatever the diet the classification of the countries by order of decreasing cake supplies is generally the same. Only France's position in relation to Switzerland is occasionally modified. Germany's cake supplies are the highest and Denmark's the lowest. The cake supplies recommended by Greece, France, the Netherlands, Sweden and Switzerland differed by a maximum of $100 \mathrm{~g}$ (fig. 3).

1) FATTENING FRIESIAN BULLS $(200 \mathrm{~kg}-1000 \mathrm{~g} / \mathrm{d})$

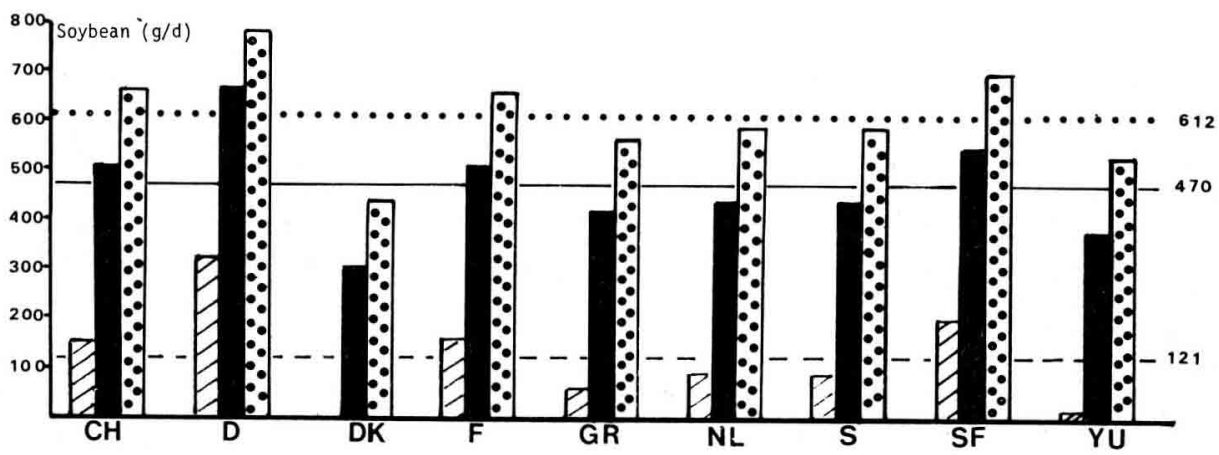

2) GROWING FRIESIAN HEIFERS (200 $\mathrm{kg}-700 \mathrm{~g} / \mathrm{d})$

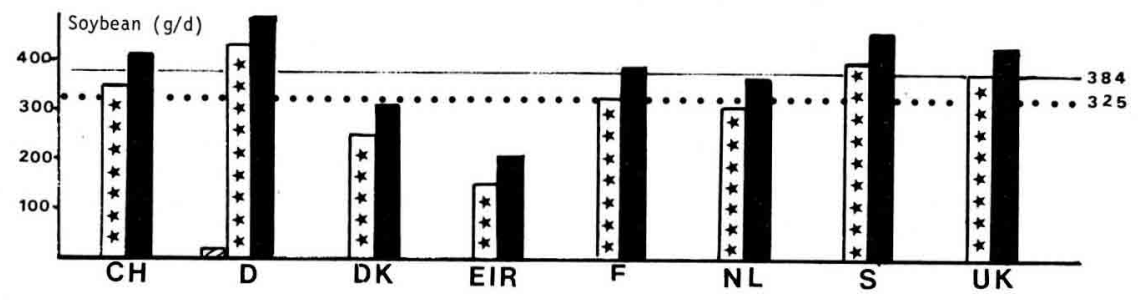

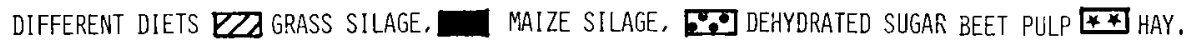

Fig. 3. - Comparison of the complementary soyabean meal supply $(g / d)$ by the different countries for different diets. 
As we have stated, the maïze silage diet and the pulp diet need more cake than the grass silage diet. Yet between countries the increment of cake varies with the type of diet (fig. 4) and as a consequence of the differences in cake supplies between countries.

For growing heifers, the widest differences in soyabean cake supplies vary from 20 to $280 \mathrm{~g}$ according to the diets (fig. 3). German supplies are the highest, and Irish the lowest. The cake supplies recommended by $\mathrm{CH}, \mathrm{F}, \mathrm{NL}$ and UK differ at most by $70 \mathrm{~g}$. However, as with young bulls, the differences in cake supplies between countries vary with the type of diet (fig. 4).
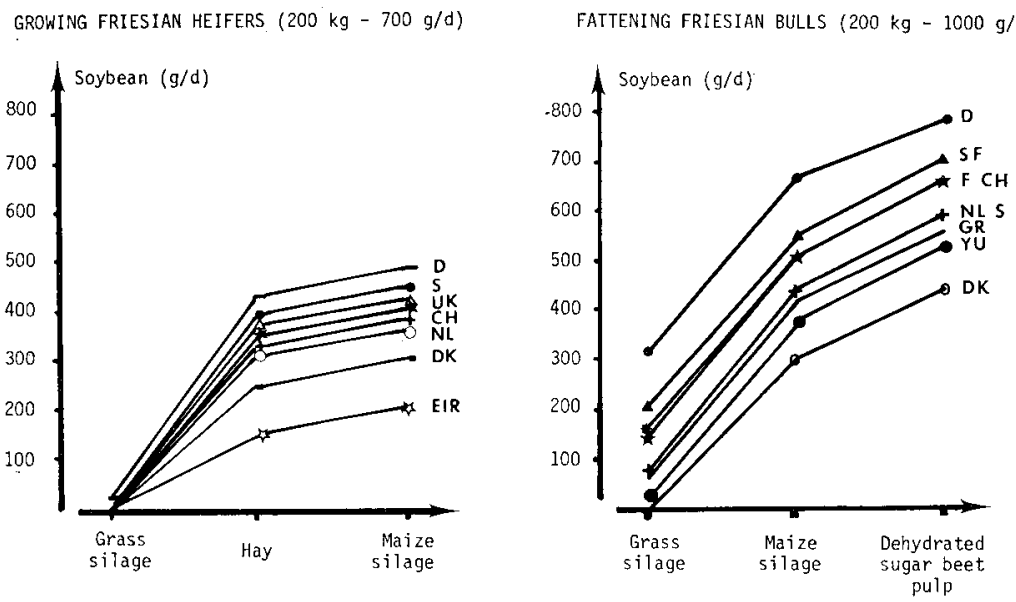

FIG. 4. - Evolution of the complementary soyabean meal $(\mathrm{g} / \mathrm{d})$ supply with the nature of the diet in different countries.

\section{3. - The present situation of recommended supplies with new protein standards}

The analysis of supplies recommended by the EEC and associated countries revealed some discrepancies in their evolution as a function of weight and weight gain, in their absolute and relative values and in the diet composition which these supplies lead to.

These discrepancies are due to the methods of calculating requirements and also to the way in which these requirements are expressed. Although the explanation of their calculations has not always been explicit, it appears that some have been determined by a factorial method. Thus differences between countries depend on values chosen for physiological needs and for efficiency of utilisation of the DCP. Others are the results of feeding trials and lead to protein recommendations that vary according to the type of diet.

In contrast, other systems, such as the INR $A$ System in France, recommend protein supplies independent of the nature of the diet. They express the physiological requirements of the animals by the quantity of truly digestible $\mathrm{N}$ amino acids in the small intestine. Furthermore, they allow :

1. The nitrogen source best suited to the given diet and to the animals' needs, to be chosen : thus, for example, the French DCP recommended for young 
bulls leads to $660 \mathrm{~g}$ of soyabean or $630 \mathrm{~g}$ of peanut as a supplement of dehydrated pulp. This system does not take into account the greater degradability in the rumen of peanut cake compared to soyabean cake, nor does it take into account the microbial synthesis potential allowed by glucids from pulp digestible in the rumen which require an additional supply of soluble nitrogen. On the other hand the PDI calculation calls for $720 \mathrm{~g}$ of peanut or $380 \mathrm{~g}$ of soyabean associated with $50 \mathrm{~g}$ of urea, or $210 \mathrm{~g}$ of treated soyabean cake (which is not degradable in the rumen) with $75 \mathrm{~g}$ of urea, to supply the soluble nitrogen required by the rumen micro-organisms.

2. The optimal level of urea to be determined, when its utilisation is possible, when three supplementary feeds are used (barley (B); soyabean (S) ; urea (U)). This optimal level of urea remains uncertain in the DCP system. To make up the energy and DCP deficit only two equations can be used:

$$
\begin{aligned}
& 0.88(\mathrm{UFV})=1.16 \mathrm{~B}+1.19 \mathrm{~S} \\
& 331(\mathrm{DCP})=94 \mathrm{~B}+491 \mathrm{~S}+2000 \mathrm{U}
\end{aligned}
$$

The optimal level of urea is between 0 and $30 \mathrm{~g} / 100 \mathrm{~kg}$ body weight (given the maximum amount). In contrast, in the PDI system, as each feed, and then each forage, contributes to the microbial protein synthesis both by the degradable $\mathbf{N}$ and the available energy that it supplies to the rumen micro-organisms, three equations can be used to make up the deficit and obtain only one solution :

$$
\begin{aligned}
& 0.88(\mathrm{UFV})=1.16 \mathrm{~B}+1.19 \mathrm{~S} \\
& 260(\mathrm{PDIN})=88 \mathrm{~B}+385 \mathrm{~S}+1610 \mathrm{U} \\
& 149(\mathrm{PDIE})=116 \mathrm{~B}+285 \mathrm{~S}
\end{aligned}
$$

TABLE 2

INFLUENCE OF THE NATURE OF $N$ SOURCE ON THE GAIN OF YOUNG BULLS (ITCF, $1971-1972$ )

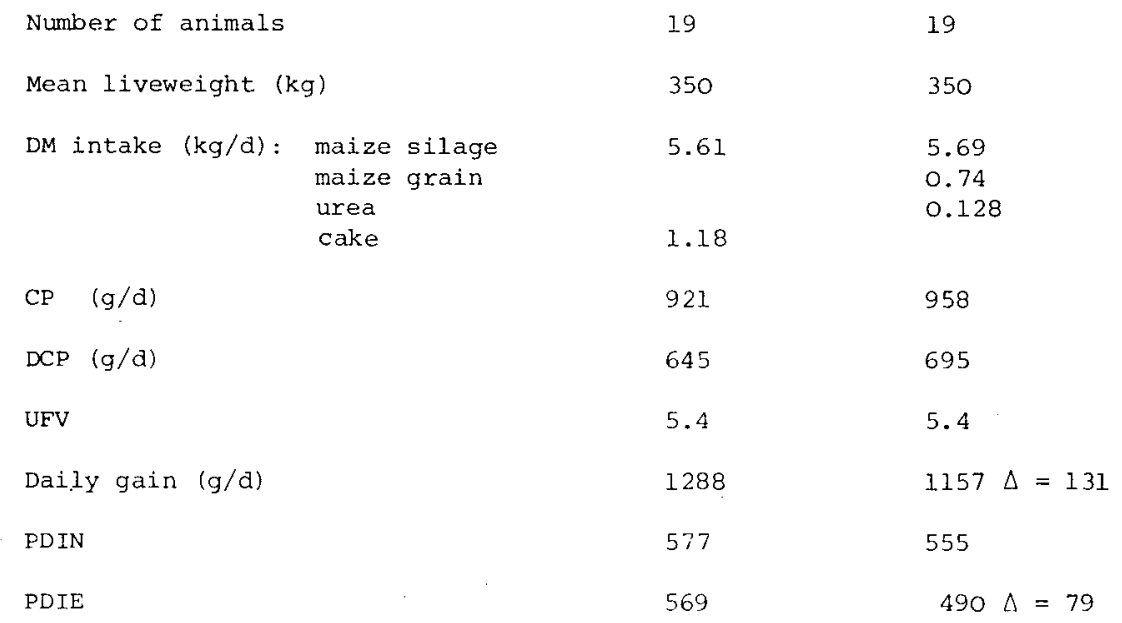


3. To explain the differences in daily gain observed experimentally between groups of animals fed identical amounts of DCP from different nitrogen sources. Thus, in the ITCF experiments $(1971$ - 1972) (table 2) the lower gain with urea $(131 \mathrm{~g} / \mathrm{d})$ compared to $\mathrm{N}$ protein sources when animals received the same amount of energy and DCP, can be explained by a lower PDI supply (79 g/d).

Different authors have also attempted to express the protein requirements of the cattle by the total amino acid $\mathrm{N}$ absorbed in the small intestine (cf. VÉRITÉ et al., 1979). As a comparison we calculated the complementary supplies in the ROY System (1980) for Friesian heifers. We compared them to previously calculated supplies in DCP and to supplies in the INRA System. Regardless of the diet the ROY System does not require any supplementary protein N (fig. 5). The microbial amino acids which result from the available energy content of the diet were always sufficient to satisfy the amino acid requirements of the tissues. The lack of protein supplies disagrees with the recommendations of the other countries, notably with those of the UK.

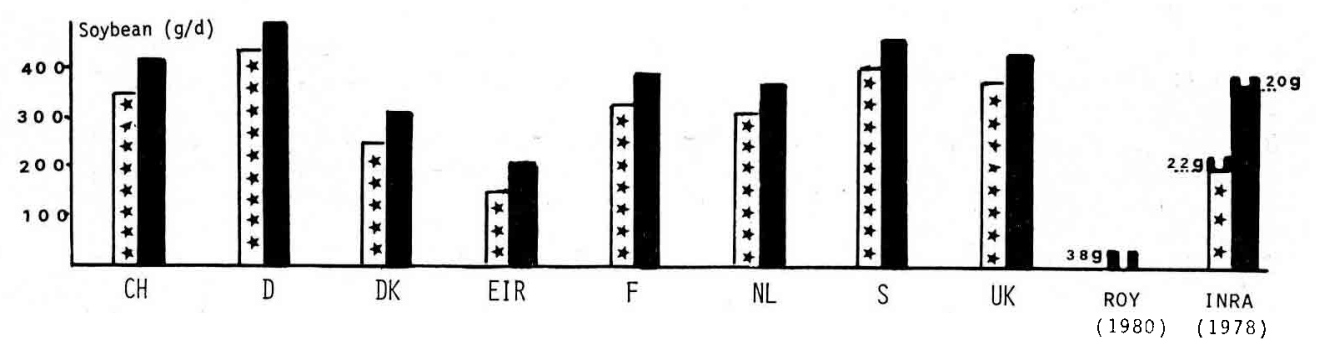

*\# HAY MÄ̈ZE SILAGE

FIG. 5. - Comparison of the complementary soyabean meal supply for different diets, in DCP system (for different countries) and in the new systems (Roy, 1980;INRA, 1978).

These discrepancies in protein recommendations, especialiy between $R O Y$ and the PDI System, are due mainly to the differences in calculated physiological needs of the animals (maintenance requirements at $200 \mathrm{~kg}$ of $\mathrm{LW}: 1.10 \mathrm{~g} / \mathrm{W}^{\circ, 75}$ of amino acid $\mathrm{N}$ apparently digestible in the intestine in the ROY System compared to $3.25 \mathrm{~g} / \mathrm{W}^{0.75}$ truly digestible in the $P D I$ System) and to the differences in efficiency of amino acid utilisation (O.75 versus 0.60$)$.

\section{Conclusion}

From this analysis it appears that the protein quantities recommended by the different countries :

1. do not take into account all the factors of yariation in protein deposition such as sex, breed or liveweight gain ;

2. do not vary either with the same magnitude or in the same way with weight and daily gain. The variation between countries amounted to from 17 to 32 per cent of the mean value, depending on the type of animals. Some protein standards, however, $(\mathrm{CH}, \mathrm{F}, \mathrm{NL}$, for bulls, or $\mathrm{CH}, \mathrm{F}, \mathrm{NL}$, UK for heifers) did not differ much in the more useful range of gain; 
3. depend on the nature of the diet when they are expressed in DCP. So it would be preferable to express them in a more independant system which would better estimate the true protein value of the feeds and the physiological needs of the animals. However, these net requirements, the metabolic efficiency of utilisation of amino acids flowing in the intestine and, lastly, the criteria used to estimate the protein value of feeds need to be studied more accurately.

\section{References}

GeaY Y., Robelin J., JARRIge R., 1976. The influence of the metabolisable energy content of the diet on the efficiency of energy utilisation for young fattening bulls. 7th. Symp. Energy Metab., Vichy, EAAP, 19, 225-229.

I.N.R.A., 1978. Alimentation des Ruminants. Ed. I.N.R.A. Publications (Route de St-Cyr), 78000 Versailles.

ITCF-SEPAJEBO Confrancon, 1971. Compte rendu d'expérience $\mathrm{n}^{\circ} 1$.

ITCF-SEPAJEBO Confrancon, 1972. Compte rendu d'expérience $n^{\circ} 3$.

Robelin J., GeAY Y., Bonaiti B., 1978. Genetic variations in growth and body composition. E.E.C. Seminar on "Patterns of Growth and Development in Cattle», Ghent, EUR 6007 EN, Martinus Nijhoff, The Hague, 443-460.

Robelin J., Daenicke R., 1980 . Variations of net requirements for cattle growth with liveweight, liveweight gain, breed and sex. EEC Seminar on « Energy and Protein Feeding Standards for Beef Cattle », Theix, November 1979. Ann. Zootech, 1980, 29 n $^{\circ}$ H.S., 99-118.

RoHR K., DAENICKE R., 1978. Inffuence of nutrition on the growth pattern of fattening bulls of two different breeds (Friesian and Simmental). EEC Seminar on « Patterns of Growth and Development in Cattle 》, Ghent, EUR 6007 EN, Martinus Nijhoff, The Hague, 413-421.

RoY J.H.B., 1980. Protein utilisation - the basis of feeding standards for protein in growing and fattening beef cattle. EEC Seminar on « Energy and Protein Feeding Standards for Beef Cattle », Theix, November 1979. Ann Zootech., 1980, 29 no H.S., 161-171.

Vérité R., Journet M., JARrige R., 1979. A new system for the protein feeding of ruminants : the PDI System. Liv. Prod. Sci., 6, 349-367. 


\title{
Discussion
}

\author{
Chair : R. JARRIGE (France)
}

J.H.B. Roy $(U K)$. - I do not have a preview of the paper so I do not really know quite how the calculations were done, but $I$ think the reason for this so-called discrepancy in the maintenance value between the proposed ARC system and the PDI system, is the fact that the maintenance requirement, as used by the speaker just now, is maintenance based on the endogenous urinary $\mathrm{N}$ value plus losses in the hair and scurf. This is not actually the maintenance requirement of the animal if it is below the maintenance requirement of the micro-organisms in the rumen. The maintenance requirement for the microorganisms is considerably higher than the maintenance requirement for the animal. If you use the maintenance requirement for the micro-organisms, i.e. $\mathrm{RDP}=7.8 \times \mathrm{ME}$, you will find that gives a much more equivalent figure.

G. Alderman $(U K)$. - On the same point, may I ask Dr. Geay what degradability value he took for the maize silage in the calculations attributed to the Roy system?

\section{Y. Geay (France). - It was 55 per cent.}

G. Alderman. - In making the calculations on the rations that we were asked to look at for the $200 \mathrm{~kg}$ animals in the ARC system, we would be suggesting that ration 3, which has maize silage in and which has $0.5 \mathrm{~kg}$ of soya added to it, would be marginal for rumen degradable protein. We would think of putting in a little bit of urea. Ration 5, which gives a predicted gain of $0.5 \mathrm{~kg} /$ day in our system, also is just approaching a small supplement - $20 \mathrm{~g}$ of urea/day. That also has $0.5 \mathrm{~kg}$ of soya/day. So, I think we should not necessarily accept your conclusion as being representative of the ARC system until we have checked that we are firmly on the same data base. In my judgement, both rations 3 and 5, using the ARC system, would require supplementary urea as well as the $0.5 \mathrm{~kg}$ of soya.

Y. GEAY. - I think it depends on the quality of the different feedstuffs chosen.

I would like to make some further comments. The classification and the difference of the relative values between the different countries also depend on the energy value chosen for the feedstuffs and the energy requirement chosen for the animals. In fact they are not absolute values but give some idea of the variation which it is possible to observe between countries.

R. JARRIGE (France). - On the point made by Dr. Roy, I think the initial data used in the two systems are quite similar but used in different ways. The main difference is that the ARC use an apparently digestible protein in the small intestine and we use a true digestibility in the small intestine. So, we have to take into account the endogenous losses. In your system as in the digestible crude protein systems, the endogenous losses are in the values of the feedstuffs. The main weakness of our system is the estimation of the maintenance requirements. They may be a little high. The second difference is probably more philosophical. You are feeding the rumen microbes more than the animal and we are feeding first the animal. This brings in some differences between the two systems.

Y. Geay. - May I ask Dr. Roy for the explanation of the value chosen for the efficiency of amino acid utilisation. Is the value of 0.75 an experimentally observed one, or not? What is the reason for choosing this value?

J.H.B. Roy. - As with some of the other values it is based on somewhat limited evidence. This was based on experiments done with ruminant calves of about $150 \mathrm{~kg}$ liveweight, of which some were fitted with duodenal and ileum re-entrant cannulas, while others were intact. They were fed either groundnut or fishmeal as a source of protein, with crude protein contents per $\mathrm{kg}$ of dry matter varying from 9 per cent to 35 per cent. Naturally we got the disappearance of protein, or amino acid $\mathrm{N}$, between the duodenum and ileum. The other calves which were intact were fed exactly the same amounts of the diets at 
exactly the same ages and we measured $\mathrm{N}$ retention on them and where protein was just limiting. 0.75 was the efficiency of utilisation of amino acids calculated from the apparent disappearance of amino acid nitrogen for $\mathrm{N}$ balance plus endogenous urinary nitrogen. That is how the value was obtained. It is from limited information but, in fact, we have some more recent evidence with pre-ruminant animals where we have been using milk protein and also various proportions of single cell protein. Using exactly the same system as with the ruminant animal we have had a value of $0.75-$ and that is with the milk protein where one assumes that the amino acids are pretty well balanced in relation to the concomitant demands for the tissues. So, I think 0.75 may be a maximum but it is a possibility.

A.J.H. VAN Es (The Netherlands). - I think here we have about the same situation as with energy. We have the theoretical system which maybe had even more uncertainties than in the case of energy evalution. We have also results from practical feeding trials but $I$ think the results from those trials are also weak. First, there is the weakness with regard to the energy and on top of that there is the weakness with regard to protein. So, we are trying to level out two systems - a theoretical one and a practical one - and both are very rough. Is that not true? Most of the discussion just now has been on the new systems; on the face of it they look very precise but I think the basic information is somewhat doubtful - degradability, maintenance requirements, absorbability of amino acids from the gut. Perhaps we should consider both again, the feeding trial results as well as the new approach, and try to mix them in a sensible way.

R. JARRIGE. - If we consider the DCP systems which have been, and are used almost everywhere, there is a difference with the energy systems. It is that the DCP values of the feedstuffs are quite similar in the different countries. They are based on digestibility trials which are quite satisfactory. So the differences between the standards probably arise from the differences in the feeding trials used and from the differences in the rations used in the trials. The second difference is probably in the measurement of the results of the feeding trials. You can say that the requirements are the quantities which allow the maximum daily gain, or you can say that they are a little lower. It is clear that the protein has some other role than to supply the protein needs. If you feed more amino acids inside the intestine, in certain circumstances, you will have an increase in the liveweight gain. The third difference probably lies in the variation between the animals used. Certain experiments were done with steers which do not have the same requirement as bulls, for example. However, if we use the DCP systems to improve the situation, we have two solutions. Either we modify the value of the feedstuffs to take into account their degradability, or we modify the requirements and say the recommendation for maize silage is $500 \mathrm{~g}$, the recommendation for grass silage is $400 \mathrm{~g}$, and so on. If you use DCP systems you have to make a clear choice between the two if you want more comparable results between countries.

A.J.H. VAN Es. - Of course, it is not only a question of degradability. Let's say, if you have starch, how much microbial protein can be produced? So you have to have information on both.

R. JARRIGE. - Yes of course. This is the reason why in our system we have two values, one for nitrogen content and one for energy content.

G. Alderman. - I would agree with Dr Jarrige's analysis of the situation and my concern is that we now have decades of feeding trials where in the light of either the UK or the French models of protein utilisation, we are not comparing like with like.

My question would be related to the use of feeding trials to determine protein requirements. Dr Geay hinted that perhaps one should aim for maximum gain or possibly less than maximum. Now, just how sensitive are feeding trials in this area; is this a workable way of deciding protein requirements or do we have to fall back on a net protein approach which is what both the UK and French models attempt? If you know what the net protein gain is, you can work back to what the requirement should be. Is it realistic to say that you can use feeding trials to determine digestible crude protein requirements? We still use Dr. Roy's standards and it might be interesting if he would comment on the basal diet which lies behind the UK DCP standards, and on the approach he used - optimum, maximum, or something less than that.

J.H.B. Roy. - I did not realise until recently that the standards I produced in 1959 were being used by the UK advisory service. I was asked to review the nutrient requirements 
of calves back in 1959. For protein I surveyed the factorial system, as proposed by Mitchell and subsequently developed by Blaxter and Mitchell, and also the results of Lofgreen and Kleiber plus the requirements from feeding trials by Bailey and Broster among others. Basically, having plotted all these curves I put in the best fit for I $1 b$ gain/day and $2 \mathrm{l} b \mathrm{gain} /$ day over the range in liveweight from $100 \mathrm{lb}$ up to $1000 \mathrm{lb}$. There were no statistics to it; it was just a case of the best fit 'by eye'.

\section{R. JARRIGE. - Why are there such large differences between Denmark and Germany?}

Y. GeAY. - Our German colleagues are not here but I should mention that in the paper sent by Dr. Daenicke, he says that the recommendations are $10-20$ per cent higher than the animals' requirements calculated in this country.

A. NeImann-S $\varnothing$ RENSEN (Denmark). - I think my colleagues will comment on our norms but for fattening animals they have been revised recently and they have been reduced.

I have a specific question for Dr. Roy : in the new system you work with degradable protein and you put a fixed degradability to each feed. However, the feeding level is a factor here; the more you put into the rumen, the more will go through undegraded. I don't think you are taking this into account and from the model calculations we have made, it seems to be a very important factor.

J.H.B. RoY. - It is unfortunate that we have only produced a summary of the results at Flevohof a couple of years ago. In the whole volume of the new ARC 'Nutrient Requirements' which will be published next year, there is a huge chapter on protein which acknowledges the variability and the shortcomings of the new ARC system, in particular in relation to degradability. We appreciate that there are a large number of factors that may affect it - not only what is going on as far as level of feeding is concerned, but the processing, the time/temperature relationship in soyabean treatment, for example, or in dehydration of dried grass. There are a number of factors and we appreciate that this is so. It is really a matter of whether one starts to try to produce a system which is subsequently modified in line with further knowledge. At the moment the knowledge is not there to say how far solubility and various other factors affect degradability.

G. Alderman. - This system is now into what one would call the development phase. We accept entirely that whilst any particular ration will be computed on the relevant degradability, there is no such thing as $a$ degradability for $a$ food. Retention time is an important characteristic. In terms of the Orskov mathematical model, which is not the only model which will fit degradability curves, you have the initial solubility, the maximum - the asymptotic degradability, and then a constant related to time telling you how degradability changes with time. So there are three constants and a time factor lying behind this, and we accept that as being realistic, but you still come back to the situation that for a particular ration, fed at a particular level, we need to be able to put a number to the degradability. This takes us into the development and testing phase as to how sensitive the model is. The system is not accepted for use in the UK which is why I have presented DCP standards as being current practice. I am sure Dr. Roy takes great pride in the fact that his standards have lasted extraordinarily well.

A.J.H. VAN Es. - I believe that we have to move into the newer systems but first we need more information. One of the things which worries me a little is, who is producing good figures, for instance, good degradability figures at a higher feeding level in a rapidly growing beef animal ? It is very difficult to get good figures on it ; just to do the experiments you need duodenal, re-entrant fistulated animals which usually do not grow very rapidly. It is a lot of work and very few laboratories do it ; most of them work with sheep. Can we use the data from such work on sheep on rapidly growing beef cattle?

A. Neimann-Sørensen. - One is tempted to ask if there is sufficient collaboration in this area. I believe many countries are trying to establish these standards so one might well ask an audience such as this whether these efforts are well harmonised so that we do not duplicate some work and overlook other work.

T. Griffiths (Ireland). - In Ireland we have done a lot of feeding trials with beef cattle but it has been extremely difficult with the type of diets we use to get a response from protein. The general picture this morning would indicate that we tend to get higher standards for energy and lower standards for protein than most other people. I think our 
energy standards are a function of the fact that we have higher maintenance requirements for the type of husbandry in Ireland. On the protein side, the standards which $I$ gave are as tentative as our energy standards for that matter, but they are based on some small feeding experiments where we have also measured metabolisable energy and digestible crude protein. The object was to see if we could get some information in our practical growing situation that could be related to information coming from more detailed basic experiments. The levels which we gave do include a safety margin of at least 10 per cent.

D.F. Osbourn $(U K)$. - On the question of who is doing work in this field, my colleagues are working in the field of measuring the total flow of nitrogen and microbial nitrogen into the duodenum. We have looked at maize silage, fishmeal supplements, grass silage and legume silage, and we will continue to look at these. We are also looking at grazed grass and legumes. Unfortunately, the results are slow to come out.

G. Alderman. - I believe, Dr. Osbourn, that there are also some comparative studies under way, a type of ring test for these re-entrant cannula measurements, which could be quite informative.

D.F. Osbourn. - They have not really got off the ground yet but they are planned.

R. JARRIGE. - Once more this is an area which is affected by the philosophy. On the one side you can say that the knowledge is not sufficient to change. On the other side you can say that the knowledge is sufficient to change even if it is not entirely satisfactory. This is our philosophy. With the new systems you can use a vast amount of knowledge concerning the nutrition of the rumen microbes, the use of urea, the differences between soyabean and peanut - it is not necessary to have a new experiment to know that the degradability of peanut is much higher than that of soyabean. You can easily calculate the quantity of urea necessary; you can explain the differences observed in your feeding trials, you can take into account the role of energy in protein metabolism at the rumen level and inside the animal, and you can predict the associated effects between feedstuffs. So, really the knowledge is sufficient to change from DCP, or to use modified DCP adapted to the different kinds of diet. If you are in a country where only one type of diet is used, as in some parts of the United States, you can just use crude protein content. However, if you are in a country like ours with a wide range of feedstuffs and animals, you need a system.

A.J.H. VAN Es. - I agree with you but you mentioned the degradability of soyabean meal; this can vary quite a bit, according to the heat treatment and so on.

R. JARRIGE. - I agree, but in most of our countries we want the maximum use of our roughages. The new systems, A.R.C. or I.N.R.A., allow the better use of the nitrogen production of our roughages. The compound feeds or the concentrates are only complementary. If you have an error of 20 or 30 per cent on the degradability of the cake, the system still works. Surely one can expect the errors to decrease.

Now, are there any general comments on the discrepancies between standards in the different countries? It is not suggested that we should have exactly the same system in all the countries - that would be impossible but we should have convertible systems.

A.J.H. VAN Es. - In the States they are not using a wide range of feedstuffs; for concentrate feedingstuffs it was only ten a few years ago. We use many more. As soon as you go into different kinds of forages and concentrate by-products then you need a more precise system.

J. L'Estrange (Ireland). - How great is the difference between the countries at the moment; how much is it a question of terminology rather than principle? It seems to me that in principle most of the systems are coming closer and closer together and that what is left behind is terminology.

R. JARRIGE. - No, there are really two families. For energy you have the new family based on the same framework as the A.R.C., Dutch, Swiss and French. It is expressed either in metabolisable energy or in net energy and so the net energy belongs to another family. For protein you have the traditional family and a new small family.

H. Bickel (Switzerland). - I agree with you that it is not just a question of terminology but $I$ think the aim should be agreement on certain basic new knowledge on both 
energy and protein but we cannot discuss this until we have heard all the other papers. I do not think that we can leave this seminar having agreed on one system and one set of terminology that everybody will use but, as you say, perhaps we can agree a framework for energy and protein for the future.

R. JARRIGE. - The interesting point about the new frameworks, both for energy and protein, is that the new knowledge could be taken into account very easily with the old systems.

H. Bickel. - The important problem is that at the moment there is no direct correlation and constant proportion between energy or protein evaluation under the new systems with the old systems. There are no constant factors between them and so there is no possibility to go from one evaluation system to the other.

A.J.H. VAN Es. - Co-operation between people who are working on the new protein systems was mentioned. We have the Kiel group who are doing work on rumen physiology; they meet once every year or so. The main problem is that the few people who are working with re-entrant duodenal fistulated animals are really working with high producing animals. Most of them are working with sheep rather than cattle and unforunately, most of them are working with animals which do not grow so rapidly, so that is a big problem. Then again, next year in Braunschweig we have the Protein Symposium so there is another possibility for co-operation. I think there will be an intensive discussion there on protein for beef cattle and lactating animals. 